\title{
Geochemical characteristics of sediment-pore water systems associated with hydrothermal activity at South Okinawa Trough
}

\author{
FENG-HSIN HSU ${ }^{1}$, CHIH-CHIEH SU ${ }^{1}$, HSIAO-FEN LEE ${ }^{2}$, \\ YU-SHIH LIN ${ }^{3}$, CHUNG WU ${ }^{1}$, MEI-FEI CHU ${ }^{4}$, SONG- \\ CHUEN CHEN ${ }^{5}$ AND YUNSHUEN WANG ${ }^{5}$ \\ ${ }^{1}$ Institute of Oceanography, National Taiwan University \\ ${ }^{2}$ National Center for Research on Earthquake Engineering, \\ National Applied Research Laboratories \\ ${ }^{3}$ Department of Oceanography, National Sun Yat-Sen University \\ ${ }^{4}$ Department of Geosciences, National Taiwan University \\ ${ }^{5}$ Central Geological Survey, Ministry of Economic Affairs \\ Presenting Author: fenghsinhsu@gmail.com
}

In the past half-decade, several hydrothermal fields were discovered at South Okinawa Trough. Of particular is Geolin Mounds (GLM) hydrothermal field with its vigorous activity confirmed by the gas flame observed through abnormal acoustic reflections in water column, the in-situ observations of hydrothermal fluid venting, biotic communities and seafloor massive sulfide deposits. Here, we summarized its unique geochemical characteristics of subsurface sediment-pore water systems. (1) The ${ }^{3} \mathrm{He} /{ }^{4} \mathrm{He}$ values $\left(7.45 \sim 7.62 \mathrm{R}_{\mathrm{A}}\right)$ in pore waters were higher than the average of volcanic gas from circum-Pacific volcanic arcs, reflecting an involvement of upper mantle source. (2) The downward decreasing $\mathrm{Mg}$ (down to $32.7 \mathrm{mM}$ ) and $\mathrm{Cl}$ (down to $373 \mathrm{mM}$ ) with increasing Li (up to $757 \mu \mathrm{M}$ ) in pore waters implied an obvious mixing of seawater and phaseseparation-related hydrothermal fluid. Based on two end-member mixing model of $\mathrm{Mg}$, the highest fraction of hydrothermal fluid in pore water was estimated to be $40 \%$. (3) The low $\mathrm{pH}$ values ( $\mathrm{pH}=5.67 \sim 6.21)$ with downward increasing of dissolved inorganic carbon (DIC, up to $60 \mathrm{mM}$ ) and high isotopic values $\left(\delta^{13} \mathrm{C}_{\mathrm{DIC}}=2.5 \sim 7.0 \%\right.$ o $)$ were observed in pore waters. This indicated an in-situ liquid $\mathrm{CO}_{2}$ surrounding. Furthermore, sediments related to hydrothermal alteration were found at few specific layers with significant enrichments of $\mathrm{Au}, \mathrm{Ag}, \mathrm{As}, \mathrm{Bi}$, $\mathrm{Cu}, \mathrm{Cd}, \mathrm{Pb}, \mathrm{Sb}, \mathrm{Sn}$ and $\mathrm{Zn}$. All the geochemical features found in the GLM hydrothermal field suggested the importance of secondary modification processes after high-temperature waterrock interaction, especially the interaction between hydrothermal fluid and sediment. 